\title{
Pembentukan Mata Uang Tunggal Kawasan ASEAN
}

\author{
(The Establishment Single Currency of ASEAN Region)
}

\author{
Nurul Cholifah, Diah Wahyuningsih* \\ Jurusan Ilmu Ekonomi, Fakultas Ekonomi dan Bisnis, Universitas Trunojoyo Madura \\ Jl. Raya Telang PO BOX 2 Kamal, Bangkalan, Madura \\ E-mail: diahwahyuningsih@yahoo.com
}

\begin{abstract}
Abstrak
Integrasi keuangan merupakan langkah terakhir yang bisa dilakukan untuk mencapai integrasi ekonomi. Satu syarat yang harus dipenuhi sebelum adanya penerapan integrasi keuangan adalah dengan adanya kriteria area mata uang optimal (OCA). Tujuan penelitian ini: 1) untuk mengetahui adanya kedekatan mata uang atas perubahan nilai tukar bilateral sebagai pendukung dalam kemungkinan pembentukan mata uang tunggal kawasan ASEAN, 2) menganalisis mata uang jangkar pilihan yang memiliki pengaruh positif (apresiasi) terhadap mata uang lokal kawasan ASEAN sebagai mata uang tunggal kawasan. Penelitian ini menggunakan data tahunan real output, ukuran rasio GDP, perdagangan bilateral, perbedaan komposisi perdagangan dan nilai tukar sepanjang periode 1995-2018. Metode analisis yang digunakan adalah uji data panel. Hasil penelitian menunjukkan bahwa mata uang negara ASEAN belum memiliki kedekatan pembentukan mata uang tunggal kawasan di kawasan ASEAN. Sedangkan untuk menentukan mata uang jangkar yang sesuai digunakan sebagai mata uang bersama yaitu SGD (Dollar Singapura) secara empiris memberikan pengaruh positif (apresiasi) di kawasan ASEAN dibandingkan RMB, JPY, Euro, atau USD. Oleh karena itu SGD dapat diusulkan sebagai mata uang jangkar untuk negara ASEAN.
\end{abstract}

Kata Kunci: indeks OCA, mata uang jangkar, mata uang tunggal.

\begin{abstract}
Financial integration is the last step that can be done to achieve economic integration. One condition that must be met before the implementation of financial integration is the existence of the optimal currency area (OCA) criteria. The purpose of this study: 1) to find out the closeness of the currency to changes in the bilateral exchange rate as a supporter in the possibility of forming a single currency in the ASEAN region, 2) to analyze the chosen anchor currency which has a positive influence (appreciation) on the local currency of the ASEAN region as a currency single money region. This study uses annual real output data, size of GDP ratio, bilateral trade, differences in the composition of trade, and the exchange rate throughout of 1995-2018 period. The analytical method used is panel data test. The results showed that the currencies of ASEAN countries did not yet have the closeness of forming a single currency in the ASEAN region. Meanwhile, to determine the appropriate anchor currency to be used as a shared currency, namely SGD (Singapore Dollar) empirically has a positive influence (appreciation) in the ASEAN region compared to RMB, JPY, Euro, or USD. Therefore SGD can be proposed as an anchor currency for ASEAN countries.
\end{abstract}

Keywords: OCA index, anchor currency, single currency.

\section{Pendahuluan}

Sampai pada dua dasawarsa terakhir, kebijakan nilai tukar di negara-negara ASEAN, akan terus dijadikan lahan observasi kritis oleh para peneliti. Kajian kritis tersebut diantaranya, mengenai kepedulian tentang negara-negara ini dalam mendapatkan keunggulan kompetitif melalui depresiasi mata uang mereka; implikasi rezim nilai tukar pada implementasi kebijakan moneter; dan pandangan mengenai mata uang (Euro) yang merupakan suatu cerminan dari adanya struktur kekuatan ekonomi global (Henning, 2012).

Salah satu negara yang telah berpengalaman dalam membentuk mata uang tunggal yaitu negara di wilayah Eropa Union. Diberlakukannya mata uang Euro secara resmi pada 1 Januari 2002, telah menandai tahap akhir dari persatuan moneter Uni Eropa (UE). Economic and Monetary Union (EMU) yang secara historis belum pernah terjadi sebelumnya, termasuk kriteria konvergensi ekonomi secara ketat, dan tidak diimbangi di tingkat Uni Eropa (UE), sehingga pemerintah menerapkan kebijakan fiskal pan-EU (Crowley, 2015).
Dalam perjanjian Maastricht, memuat adanya keputusan mengenai penggunaan mata uang Euro sebagai mata uang tunggal di wilayah Uni Eropa. Perkembangan mata uang Euro sebagai mata uang tunggal kawasan dapat bertahan dengan baik, dan mampu menduduki peringkat mata uang nomor dua di dunia. Serta menjadi pilihan alternatif ketika mata uang Dollar dalam keadaan tidak stabil. Dengan adanya keberhasilan mata uang Euro menjadi mata uang tunggal di Eropa, menjadikan motivasi bagi negara-negara kerjasama di wilayah kawasan lain, dalam upaya pembentukan mata uang tunggal kawasan khususnya di wilayah ASEAN.

Terjadinya krisis keuangan yang melanda wilayah Asia pada tahun 1997 - 1998 berdampak pada hampir seluruh negara di wilayah Asia Timur pada bulan Juli 1997 yang menimbulkan adanya kepanikan, hingga perekonomian di dunia mengalami keruntuhan yang diakibatkan karena adanya penularan keuangan. Adanya krisis tahun 1997-1998 di Asia membuat banyak negara terkena dampak yang sangat signifikan, diantaranya mengenai nilai mata uang di sebagian wilayah Jepang dan Asia Tenggara menurun, bursa saham dan nilai aset lainnya jatuh, serta hutang kepada swasta juga

\footnotetext{
* Corresponding author
} 
mengalami kenaikan secara drastis (Friskandini, 2016). Selain itu, Siswanto dalam Friskandini (2016) mengatakan bahwa dalam kurun waktu 10 tahun, pertumbuhan ekonomi negara ASEAN-5 setiap tahunnya tumbuh rata-rata mencapai $8 \%$. Namun, setelah adanya krisis yang terjadi, pertumbuhan ekonomi di wilayah ASEAN mengalami penurunan dan mengakibatkan adanya perlambatan pertumbuhan ekonomi (Wiranata Kusuma et al., 2013).

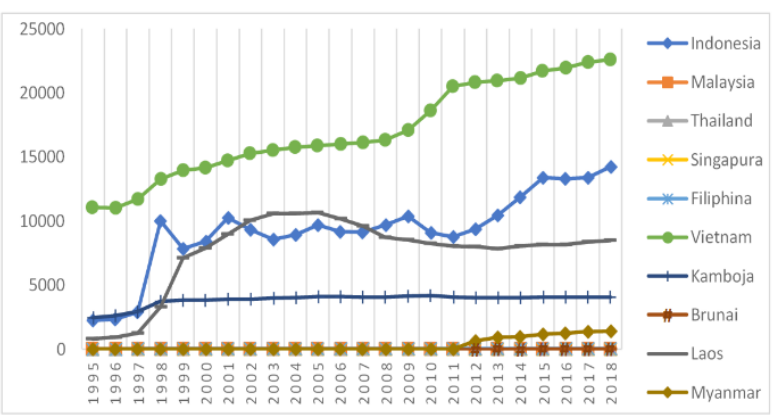

Gambar 1. Pergerakan Nilai Tukar Negara ASEAN (USD)

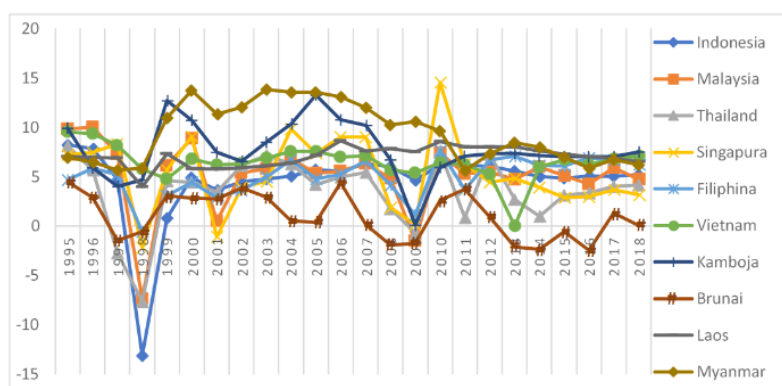

Gambar 2. Pertumbuhan Ekonomi Negara ASEAN (USD)

Sebelum adanya krisis, hanya sebagian kecil negara yang menginginkan adanya pembentukan mata uang tunggal kawasan. Namun, setelah terjadinya krisis tahun 1997-1998 di kawasan Asia, beberapa negara di wilayah Asia butuhkan struktur kerja baru untuk membentuk kerja sama pada bidang keuangan dan integrasi moneter (Mohseni \& Azali, 2014). Satu syarat yang harus di penuhi sebelum adanya penerapan integrasi keuangan adalah dengan adanya kriteria area mata uang optimal (OCA). Dari sudut pandang kerjasama ekonomi, OCA merupakan tahapan tertinggi dari proses integrasi (Achsani \& Partisiwi, 2010).

Salah satu kriteria area mata uang optimal (OCA) yang sangat penting adalah adanya pergerakan yang sama pada nilai tukar negara-negara yang ingin membentuk mata uang tunggal. Kemungkinan dari pembentukan mata uang tunggal juga memiliki ketergantungan dengan beberapa faktor ekonomi, serta untuk memenuhi kriteria pembentukan optimum currency area. Hal tersebut dilakukan untuk memberikan jaminan bahwa integrasi keuangan dapat memberikan keuntungan yang lebih besar, jika dibandingkan dengan biaya yang ditanggung oleh negara kawasan ataupun negara yang secara individu, bergabung dalam integrasi keuangan tersebut. Selain itu dapat mengurangi adanya dampak ekonomi yang terjadi setelah adanya pembentukan mata uang tunggal kawasan (Friskandini, 2016).
Langkah selanjutnya yang dapat ditempuh untuk dapat membentuk mata uang tunggal kawasan adalah dengan adanya penetapan mata uang jangkar. Mata uang jangkar (anchor currency) merupakan sebutan untuk mata uang yang menjadi pilihan untuk negara yang memakai system kurs, untuk dapat meningkatkan nilai tukar mata uang domestik. Mata uang jangkar yang biasanya dipakai merupakan jenis mata uang kuat dunia yang peredarannya dapat diterima oleh khalayak luas (Alvarado, 2014).

Beragam penelitian telah berkembang dan berusaha untuk mengidentifikasi berbagai permasalahan terkait dengan pembentukan mata uang tunggal kawasan. Penelitian (Ahn et al., 2006) menyatakan bahwa negara ASEAN-5, Hongkong, Korea Selatan, Taiwan dan Jepang bisa membentuk currency area pada saat keadaan makroekonomi mengalami ketidakstabilan untuk membentuk kawasan mata uang tunggal. Selain itu, menurut Salvator dalam Friskandini, (2016) pembentukan mata uang tunggal bisa mengurangi terjadinya ketidak- pastian rezim flexible exchange rate, memberikan dorongan adanya keahlian dalam produksi, investasi diantara negara anggota, dan aliran perdagangan. Sementara itu, Alvarado (2014), Kawai dan Pontines (2014) mampu menjelaskan bahwa pembentukan mata uang tunggal kawasan tak hanya melihat respon guncangan, akan tetapi melalui pergerakan nilai tukar yang sama dengan pengaruh siklus bisnis dari perubahan output yang terlihat, ukuran ekonomi suatu negara, hubungan perdagangan dan komposisi ekspor.

Penelitian ini menggunakan teori Optimum Currency Area yang dikemukakan oleh beberapa tokoh seperti Mundel (1961), Kinnon (1963), dan juga Kennen. Serta teori keuntungan dan biaya dari adanya pembentukan mata uang tunggal oleh Mongelli (2002).

Adapun tujuan dari penelitian ini diantaranya adalah untuk mengetahui adanya kedekatan mata uang pada perubahan nilai tukar bilateral serta menganalisis mata uang jangkar yang memiliki pengaruh positif (apresiasi) terhadap mata uang lokal kawasan ASEAN sebagai mata uang tunggal.

\section{Metode}

\section{Jenis dan Sumber Data}

Menggunakan data sekunder tahunan dari 10 negara anggota ASEAN yaitu Malaysia, Indonesia, Philipina, Thailand, Laos, Singapura, Vietnam, Kamboja, Brunei Darussalam, dan Myanmar. Data pada penelitian ini bersumber dari Bank Indonesia, Worldbank, International Monetary Fund (IMF), International Financial Statistic serta Comtrade. Data yang digunakan yaitu data real output, perdagangan bilateral, perbedaan komposisi perdagangan, data nilai tukar dan ukuran rasio GDP. Data di mulai dari tahun 1995-2018. Menggunakan dua macam uji yaitu uji OLS dan uji regresi menggunakan data panel. Indeks OCA digunakan untuk melihat adanya pergerakan yang sama pada nilai tukar bilateral antar negara angota ASEAN. Sedangkan untuk mata uang alternatif pilihan kawasan (Eropa Euro, JPY, RMB, USD, dan Singapura Dollar) digunakan untuk melihat adanya respon (apresiasi) pada mata uang kawasan (ASEAN), yang kemudian dapat diusulkan sebagaimata uang tunggal kawasan ASEAN. 


\section{Metode Analisis}

Menggunakan model data panel statis untuk mengetahui kemungkinan pembentukan mata uang tunggal kawasan dengan menggunakan alat bantu eviews 9. Menurut Widarjono dalam Prasanti et al. (2015) gabungan antara data cross section dan data time series dinamakan data panel. Selain itu, penelitian ini menggunakan analisis data panel karena ingin melihat kemungkinan dari adanya pembentukan mata uang tunggal kawasan, serta pilihan mata uang jangkar sebagai alternatif mata uang pilihan yang bisa digunakan.

Dalam penelitian ini menggunakan model yang diadopsi oleh Bayoumi dan Eichengreen (1997) melalui nilai indeks dalam uji pembentukan Optimum Currency Area. OCA indeks merupakan nilai prediksi dari variabilitas nilai tukar. Variabel nilai tukar diukur menggunakan standar deviasi dari perubahan dalam bentuk logaritma nilai tukar bilateral antara negara $i$ dengan negara $j$. Apabila Nilai OCA Indeks menunjukkan nilai yang semakin rendah maka keuntungan dalam membentuk currency union akan semakin meningkat jika dibandingkan dengan biaya yang dikeluarkan.

Model penentuan nilai indeks dalam uji pembentukan Optimum Currency Area sebagai berikut:

$$
S D(e)_{i j}=\alpha+\beta_{1} S D\left(\Delta Y_{i}-\Delta Y_{j}\right)+\beta_{2} T R A D E_{i j}+\beta_{3} S_{I Z E_{i j}}+\beta_{4} D_{I S S I M}+\varepsilon_{X}
$$

Dimana $S D(e)_{i j}$ adalah standar deviasi dari perubahan sistem logaritma nilai tukar antara negara $i$ dengan negara ;

$S D\left(\Delta Y_{i}-\Delta Y_{j}\right)$ adalah standar deviasi dari perbedaan logaritma output riil antara negara $i$ dengan negara $j$;

$T R A D E_{i j}$ adalah rata-rata dari rasio ekspor bilateral terhadap GDP domestik antara negara $i$ dengan negara $j$;

$S_{Z} E_{i j}$ adalah rata-rata logaritma GDP antara negara $i$ dengan negara $\mathrm{j} ; \quad$ DISSIM $_{i j}$ adalah jumlah dari perbedaan absolut dalam perdagangan pangsa dari agrikultur, mineral, dan manufaktur pada total barang yang di perdagangkan antara negara $i$ dan negara $j ; \quad \alpha$ dan $\beta$ adalah parameter regresi, $\varepsilon_{X}$ merupakan error term.

Dalam penentuan mata uang jangkar yang dapat digunakan sebagai mata uang tunggal alternatif kawasan dapat dilakukan dengan menggunakan regresi OLS.

Model regresi mata uang jangkar:

$$
\begin{aligned}
& \Delta \log \left(\frac{x}{N Z D}\right)=\alpha_{0}+\beta_{1} \Delta \log \left(\frac{U S D}{N Z D}\right)+\beta_{2} \Delta \log \left(\frac{\text { Euro }}{N Z D}\right) \\
& +\beta_{3} \Delta \log \left(\frac{R M B}{N Z D}\right)+\beta_{4} \Delta \log \left(\frac{J P Y}{N Z D}\right)+\beta_{5} \Delta \log \left(\frac{S G D}{N Z D}\right)+\varepsilon_{X} \quad . .
\end{aligned}
$$

Dimana x merupakan mata uang lokal kawasan negara anggota ASEAN. USD adalah US Dollar. Euro merupakan mata uang Eropa Union Euro. RMB merupakan mata uang China. Yen merupakan mata uang negara Jepang, dan SGD merupakan Singapura Dollar. $\Delta_{e}$ merupakan logaritma nilai tukar, $\varepsilon_{X}$ merupakan error term, dan $\alpha$ merupakan parameter regesi.

Kawai dan Pontines (2014) menyebutkan bahwa digunakannya mata uang Dollar New Zealand (NZD) sebagai penyebut karena mata uang ini terbuka tanpa adanya control nilai tukar serta control kapita dan bergerak mengambang bebas dari ekonomi kecil. Oleh karena itu, dapat menjadi pertimbangan untuk mengukur mata uang Asia khususnya wilayah ASEAN yang di teliti pada penelitian kali ini.

Estimasi model regresi data panel dapat dilakukan dengan menggunakan 3 pendekatan yaitu Common Effect Model (CEM), Fixed Effect Model (FEM), Random Effect Model (REM).

Teknik estimasi model regresi data panel yang paling sederhana adalah dengan menggunakan CEM. Dalam estimasinya dilakukan menggunakan OLS. Modelnya dapat dinyatakan sebagai berikut:

$$
\begin{gathered}
y_{i t}=\alpha+x_{i t} \beta+\mu_{i t} \\
\mathrm{i}=1,2, \ldots, \mathrm{N} ; \mathrm{t}=1,2, \ldots, \mathrm{T}
\end{gathered}
$$

Gujarati (2003) mengungkapkan bahwa cara untuk melihat adanya heterogenitas unit cross section pada model regresi data panel dalam pendekatan Fixed Effect Model, yaitu dengan membiarkan adanya nilai intersep yang berbeda-beda dalam setiap data cross section, namun masih menggunakan asumsi slope konstan. Persamaan FEM:

$$
\begin{gathered}
y_{i t}=\alpha_{1}+x_{i t} \beta+\mu_{i t} \\
\mathrm{i}=1,2, \ldots, \mathrm{N} ; \mathrm{t}=1,2, \ldots, \mathrm{T}
\end{gathered}
$$

Adanya perbedaan intersep dari masing-masing individu

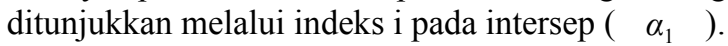

Setiap unit cross section nya mempunyai perbedaan intersep, hal tersebut merupakan asumsi dari pendekatan Random Effect Model (REM). $\quad \alpha_{1}$ merupakan variabel acak dengan mean $\alpha_{0}$. Sehingga intersep dapat ditulis sebagai

$\alpha_{1}=\alpha_{0}+\varepsilon_{i}$, dengan $\varepsilon_{i}$ merupakan error random yang mempunyai mean nol dan varian $\sigma_{\varepsilon}^{2}$. Persamaan REM dapat dinyatakan sebagai berikut:

$$
y_{i t}=\alpha_{0}+x_{i t} \beta+w_{i t}
$$

$\mathrm{i}=1,2, \ldots, \mathrm{N} ; \mathrm{t}=1,2, \ldots, \mathrm{T}$

Dengan $w_{i t}=\varepsilon_{i}+\mu_{i t}, \quad \varepsilon_{i} \quad$ merupakan komponen errorcross section, dan $\mu_{i t}$ adalah error secara menyeluruh yang merupakan kombinasi cross section dan time series.

Untuk pemilihan model terbaik yang dapat digunakan, terdapat beberapa langkah pengujian antara lain:

Uji Chow, dilakukan untuk memilih model estimasi terbaik antara CEM dan FEM, dengan $\mathrm{H}_{0}: \alpha_{1}=\alpha_{2}=$

$\alpha_{3}=\ldots=\alpha_{N} \quad$ (model CEM); $\mathrm{H}_{1}:$ minimal ada satu $\alpha_{1} \neq \alpha_{N} \quad$ (model FEM).

Statistik uji Chow dinyatakan pada persamaan berikut (Greene, 2008):

$$
F=\frac{\left(S S E_{C E M}-S S E_{F E M}\right) /(N-1)}{S S E_{F E M} /(N T-N-k)}
$$

Dimana $S S E_{C E M}$ adalah sum square error model CEM; $\mathrm{SSE}_{\mathrm{FEM}}$ adalah sum square error model FEM; $\mathrm{N}$ adalah banyak unit cross section; $\mathrm{T}$ banyak unit time series; $\mathrm{k}$ merupakan banyaknya parameter yang di estimasi. 
1. Uji Hausman, dilakukan jika hasil uji Chow yang sesuai adalah FEM. Uji hausman dilakukan untuk memilih model estimasi terbaik antara model FEM atau model REM. Dengan $\mathrm{H}_{0}: \operatorname{Corr}\left(\mathrm{X}_{\mathrm{it}}, \mu_{i t}\right)=0$ (model REM); $\mathrm{H}_{1}: \operatorname{Corr}\left(\mathrm{X}_{\mathrm{it}}\right.$, $\left.\mu_{i t} \quad\right) \neq 0$ (model FEM).

Statistik uji Hausman pada persamaan berikut (Greene, 2008):

$$
W=\left[\beta \wedge_{F E M}-\beta \wedge_{R E M}\right] \Psi \wedge-1\left[\beta \wedge_{F E M}-\beta \wedge_{R E M}\right]
$$

Dengan $\Psi=\operatorname{Var}\left[\beta \wedge_{F E M}\right]-\operatorname{Var}\left[\beta \wedge_{R E M}\right]$ taraf signifikan sebesar $\alpha$, maka diambil keputusan menolak 0 jika $\mathrm{W} \geq X_{(k ; a)}^{2} \quad$ dengan $\mathrm{k}$ adalah banyaknya variabel independen.

2. Uji LM digunakan untuk menguji apakah terdapat heterokedastisitas pada FEM antar kelompok individu cross section. Dengan $\mathrm{H}_{0}: \sigma_{i}^{2}=0$ (FEM memiliki struktur homokedastik); $\mathrm{H}_{1}: \sigma_{i}^{2} \neq 0$ (FEM memiliki struktur heterokedastik).

Statistik uji :

$$
\mathrm{LM}=\frac{\mathrm{NT}}{2(\mathrm{~T}-1)}\left(\frac{\mathrm{Q}_{\mathrm{i}=\mathrm{t}}^{\mathrm{N}}\left(\mathrm{T} \bar{e}_{\mathrm{i}}\right)^{2}}{\mathrm{Q}_{\mathrm{i}=\mathrm{t}}^{\mathrm{N}} \mathrm{Q}_{\mathrm{t}=1}^{\mathrm{T}} \mathrm{e}_{\mathrm{i}}^{2}}-1\right)^{2}
$$

$\mathrm{H}_{0}$ ditolak jika $\mathrm{LM}>X^{2}(\mathrm{~N}-1, \alpha)$ atau $\mathrm{p}_{\text {value }}<\alpha$, artinya model FEM memiliki struktur yang heteroskedastik sehingga untuk mengatasi harus diestimasi dengan metode cross section weighted.

\section{Hasil dan Pembahasan}

\section{Hasil}

1. Hasil Analisis Indeks Optimum Currency Area

Tabel 1. Hasil Estimasi Persamaan Indeks OCA

\begin{tabular}{|c|c|}
\hline Jumlah Periode Penelitian & 24 \\
\hline Jumlah Observasi & 1080 \\
\hline Adjusted R-square & 0.720 \\
\hline Standart Error Regresi & 0.098 \\
\hline Prob. F-stat & 0.042 \\
\hline$\alpha$ & -0.729049 \\
& $(0.0156)$ \\
\hline$\beta_{1} S D\left(\Delta \mathrm{Y}_{\mathrm{i}}-\Delta \mathrm{Y}_{\mathrm{j}}\right)$ & -0.006307 \\
& $(0.3578)$ \\
\hline$\beta_{2} T R A D E$ & -0.002462 \\
& $(0.4825)$ \\
\hline$\beta_{3} S I Z E$ & 0.696145 \\
& $(\mathbf{0 . 0 1 2 0 )}$ \\
\hline$\beta_{4} D I S S I M$ & -0.004445 \\
& $(0.0793)$ \\
\hline
\end{tabular}

Sumber: Hasil olah data eviews 9, 2020

Keterangan: Tanda (*) menunjukkan hasil yang signifikan.
2.Hasil Analisis Mata Uang Jangkar

\begin{tabular}{|c|c|c|c|c|c|}
\hline & SGD & RMB & JPY & USD & EURO \\
\hline \multirow[t]{2}{*}{ IDR } & 3.062 & 0.301 & -0.342 & -1.734 & -0.270 \\
\hline & $(0.0000)^{*}$ & $(0.6441)$ & $(0.0028)^{*}$ & $(0.0107)^{\star}$ & $(0.1030)$ \\
\hline \multirow[t]{2}{*}{ BND } & 0.977 & -0.078 & 0.012 & 0.085 & 0.004 \\
\hline & $(0.0000)^{*}$ & $(0.0122)^{\star}$ & $(0.0177)^{*}$ & $(0.0083)^{\star}$ & $(0.5705)$ \\
\hline \multirow[t]{2}{*}{ KHR } & 0.128 & -0.725 & 0.064 & 1.746 & -0.208 \\
\hline & $(0.6658)$ & $(0.3148)$ & $(0.6092)$ & $(0.0200)^{\star}$ & $(0.2564)$ \\
\hline \multirow[t]{2}{*}{ LAK } & 0.580 & -0.086 & 0.065 & 0.340 & 0.122 \\
\hline & $(0.0023)^{*}$ & $(0.8498)$ & $(0.4116)$ & $(0.4731)$ & $(0.2927)$ \\
\hline \multirow[t]{2}{*}{ MYR } & 1.313 & -0.076 & -0.102 & -0.005 & -0.128 \\
\hline & $(0.0000)^{*}$ & $(0.7063)$ & $(0.0042)^{*}$ & $(0.9802)$ & $(0.0134)^{*}$ \\
\hline \multirow[t]{2}{*}{ MMK } & -0.338 & 0.175 & 0.005 & 0.547 & 0.459 \\
\hline & $(0.8218)$ & $(0.9615)$ & $(0.9932)$ & $(0.8845)$ & $(0.6194)$ \\
\hline \multirow[t]{2}{*}{ PHP } & 0.800 & 0.152 & -0.153 & 0.194 & -0.068 \\
\hline & $(0.0000)^{*}$ & $(0.5090)$ & $(0.0002)^{*}$ & $(0.4184)$ & $(0.2409)$ \\
\hline \multirow[t]{2}{*}{ THB } & 1.234 & 0.107 & -0.031 & -0.277 & -0.046 \\
\hline & $(0.0000)^{*}$ & $(0.6649)$ & $(0.4690)$ & $(0.2825)$ & (0.4589) \\
\hline \multirow[t]{2}{*}{ VND } & 0.017 & -0.166 & -0.054 & 1.199 & -0.015 \\
\hline & $(0.8597)$ & $(0.4974)$ & $(0.2054)$ & $(0.0000)^{*}$ & $(0.8009)$ \\
\hline
\end{tabular}

Tabel 2. Hasil Estimasi Mata Uang Jangkar

Sumber: Hasil olah data eviews 9, 2020

Keterangan: Tanda (*) menunjukkan hasil yang signifikan.

\section{Pembahasan}

\section{Indeks Optimum Currency Area (OCA)}

Indeks Optimum Currency Area (OCA) digunakan untuk memberikan nilai pada perubahan standart deviasi logaritma nilai tukar dari dua negara secara berpasangan (nilai tukar bilateral). Menurut Bangake, 2007 dalam Friskandini (2016) perubahan mata uang membuat adanya dampak positif terhadap perbedaan struktur ekspor dan siklus bisnis. Hal tersebut sesuai dengan syarat terbentuknya OCA, bahwa siklus bisnis merupakan hal yang penting. Apabila kawasan tersebut mempunyai persamaan pada siklus bisnis, maka dapat membentuk mata uang tunggal kawasan, karena negara tersebut mempunyai persamaan kebijakan dalam penyelesaian masalah ketidakseimbangan.

Dari hasil uji regresi data panel di dapatkan model terbaik yaitu dengan menggunakan model FEM. Hal tersebut dapat dilihat dari hasi uji chow, tingkat prob. cross section chisquare nya 0.02 atau < tingkat kesalahan 0.05 maka $\mathrm{H}_{1}$ diterima, maka metode yang tepat untuk digunakan adalah FEM. Begitu juga pada hasil uji hausman, prob. cross section random nya 0.000 atau < tingkat kesalahan 0.05 , maka $\mathrm{H}_{1}$ diterima jadi model yang tepat digunakan pada penelitian ini menggunakan model FEM.

Tabel 1 menunjukkan hasil estimasi dari persamaan Indeks Optimum Currency Area (OCA) yang dibangun oleh Bayoumi dan Eichengreen (1997). Hasil estimasi menunjukkan bahwa indeks OCA negara ASEAN dapat diaplikasikan pada tingkat signifikasi $\mathrm{F}_{0.05}$ dengan variabel bebas merespon pengaruhnya sebesar $72 \%$ terhadap variabel dependen. Pada hasil uji $\mathrm{F}$ diperoleh hasil bahwa F - hitung sebesar 22.39 lebih besar jika dibandingkan dengan F-tabel 2.37 dengan tingkat probabilitas sebesar 0.042 atau kurang dari tingkat kesalahan 0.05. Bisa disimpulkan bahwa secara 
simultan variabel $S D\left(\Delta Y_{i}-\Delta Y_{j}\right), \quad T R A D E$, SIZE. , DISSIM berpengaruh terhadap $\operatorname{SD}\left(\mathrm{e}_{\mathrm{ij}}\right)$. Sedangkan pada uji-t terdapat satu variabel yang mempunyai pengaruh signifikan yaitu variabel SIZE.

Jumlah periode pada penelitian ini yaitu terdapat 24 periode penelitian yang di mulai dari tahun 1995-2018. Untuk jumlah observasi yang digunakan yaitu ada sebanyak 1080, jumlah observasi yang di dapatkan dihitung dari jumlah data dua negara berpasangan (i,j) yaitu ada sebanyak 45 pasang negraa yang kemudian dikalikan dengan jumlah periode penelitian sebanyak 24 .

Nilai $\alpha$ sebesar -0.729049 pada hasil regresi menunjukkan hasil negatif, yang berarti terdapat penurunan guncangan asimetrik pada kawasan ASEAN. Hal ini mendukung temuan oleh Bayoumi dan Eichengreen (1997) dan Friskandini (2016) yang menyatakan bahwa pada masing-masing kawasan penelitiannya menunjukkan adanya penurunan guncangan asimetrik. Namun hal tersebut berbeda dengan teori Bayoumi dan Eichengreen (1997) bahwa salah satu cara untuk dapat mendukung pembentukan mata uang tunggal kawasan dapat di capai dengan menaikkan guncagan simetris.

Variabel $S D\left(\Delta Y_{i}-\Delta Y_{j}\right)$ dengan koefisien -0.0063 dan tingkat prob. 0.35 78. Variabel $S D\left(\Delta Y_{i}-\Delta Y_{j}\right)$ tidak berpengaruh terhadap variabel $\mathrm{SD}\left(\mathrm{e}_{\mathrm{ij}}\right)$. Nilai negatif pada hasil estimasi menunjukkan bahwa negara ASEAN mempunyai siklus bisnis yang kecil. Adanya perbedaan kebijakan moneter pada setiap negara anggota ASEAN yang merupakan salah satu faktor untuk mendukung rendahnya siklus bisnis di wilayah ASEAN. Menurut Lestari (2011) peningkatan perdagangan bukan merupakan syarat mutlak untuk bisa menjamin adanya keselarasan siklus bisnis juga dapat dipengaruhi dengan adanya koordinasi kebijakan moneter. Friskandini (2016) mengatakan bahwa adanya siklus bisnis yang berkaitan dapat memberikan keuntungan bagi ASEAN dalam membentuk mata uang tunggal kawasan.

Variabel TRADE dengan koefisien -0.0024 dan tingkat prob. 0.4825 . Variabel TRADE tidak berpengaruh terhadap $\operatorname{SD}\left(\mathrm{e}_{\mathrm{ij}}\right)$. Beragamnya kondisi perekonomian di negara ASEAN membuat adanya spesialisai keunggulan komparatif di masing-masing negara, hal tersebut dilakukan bertujuan untuk efisiensi produksi. Apabila terdapat dua negara melakukan spesialisasi pada saat produksi suatu barang, serta memiliki keunggulan produktivitas, maka kedua negara tersebut akan mendapatkan keuntungan dari perdagangan yang telah disepakati. Karena adanya ketergantungan dan keberagaman sumber daya satu sama lain membuat negara ASEAN memilih adanya spesialisasi terhadap keunggulan komparatifnya. Adapun terdapat nilai negatif pada hubungan perdagangan menurut Krugman dalam Spanikova, 2006 dalam Friskandini (2016) melalui "The Krugman specialization hypothesis" bahwa hubungan perdagangan akan menurunkan derajat konvergensi dan siklus bisnis nasional, menyebabkan negara lebih memilih spesialisasi terhadap keunggulan komparatifnya dan meningkatkan biaya integrasi moneter.

Variabel SIZE dengan koefisien 0.6961 dan tingkat prob. 0.0120 . Variabel TRADE berpengaruh positif dan signifikan terhadap $\mathrm{SD}\left(\mathrm{e}_{\mathrm{ij}}\right)$. Yang berarti bahwa ketika SIZE mengalami kenaikan sebesar satu satuan, maka $\operatorname{SD}\left(\mathrm{e}_{\mathrm{ij}}\right)$ akan mengalami kenaikan sebesar 0.69 satuan. Hasil ini mendukung penelitian yang dilakukan oleh Alvarado (2014) mengenai besarnya ukuran ekonomi (SIZE) di wilayah ASEAN. Menurut Spanikova, 2006 dalam Friskandini (2016) SIZE yang bernilai positif menggambarkan besarnya ukuran ekonomi suatu negara. Ukuran ekonomi yang besar akan mengakibatkan perubahan nilai tukar yang lebih besar. Begitu juga sebaliknya, negara atau suatu kawasan memiliki ukuran ekonomi yang lebih kecil (bernilai negatif) dapat menerima keuntungan yang lebih besar dari sistem pembayaran dan sistem penyimpanan dari mata uang tunggal kawasan.

Variabel DISSIM dengan koefisien - 0.0044 dan tingkat prob. 0.0793. Variabel DISSIM tidak berpengaruh terhadap $\operatorname{SD}\left(\mathrm{e}_{\mathrm{ij}}\right)$. Hasil temuan penelitian ini mendukung hasil temuan Alvarado (2014) yang menyatakan bahwa variabel DISSIM pada kawasan ASEAN tidak memiliki pangaruh terhadap variabel $\mathrm{SD}\left(\mathrm{e}_{\mathrm{ij}}\right)$. Menurut Alvarado (2014) nilai negatif pada hasil estimasi menunjukkan bahwa negara ASEAN memiliki struktur perdagangan asimetrik atau struktur produksinya berbeda serta memiliki korelasi siklus bisnis yang kecil.

Melalui perhitungan indeks OCA Bayoumi dan Eichengreen (1996) negara ASEAN dianggap masih belum siap untuk dapat membentuk mata uang tunggal kawasan. Hal tersebut terjadi karena negara-negara anggota ASEAN belum memiliki kedekatan mata uang, serta hubungan perdagangan internasional. Seperti hal nya yang dikatakan oleh Frankel dan Rose, 1996 dalam Alvarado (2014) suatu negara dapat bergabung dengan kawasan mata uang tunggal jika negara tersebut memiliki kedekatan mata uang, memiliki hubungan internasional, memiliki kedekatan perdagangan, serta perubahan outputnya menunjukkan adanya siklus bisnis yang sinkron.

Perubahan output memiliki kaitan dengan siklus bisnis, ukuran ekonomi masing-masing negara, perbedaan struktur perdagangan, serta hubungan perdagangan, yang menunjukkan bahwa negara ASEAN belum siap untuk membentuk mata uang tunggal kawasan. Hal ini terjadi karena siklus bisnis di wilayah ASEAN masih belum menunjukkan adanya pergerakan yang simetris, adanya perbedaan struktur produksi dan spesialisasi keunggulan komparatif pada perdagangan di wilayah ASEAN membuat siklus bisnis menjadi kecil. Tingginya ukuran ekonomi di wilayah ASEAN juga dapat menyebabkan adanya perubahan mata uang yang semakin besar. Oleh karena itu, negara ASEAN dinyatakan belum siap untuk menerapkan pembentukan mata uang tunggal kawasan.

Pada uji asumsi klasik dari estimasi data panel hanya dilakukan dua uji, yaitu heteroskedastisitas dan multikolinieritas. Hasil uji multikolinieritas, dengan melihat nilai korelasi antar variabel. Nilai korelasi antar variabel bebas menunjukkan kurang dari 0.8 maka dapat disimpulkan bahwa model fixed effect tidak mengandung multikolinearitas. Pada hasil uji heteroskedastisitas probabilitas pada masing-masing variabel bebas serta probabilitas F-statistiknya menunjukkan hasil yang tidak signifikan atau lebih dari tingkat kesalahan (0.05) maka, pada hasil uji heteroskedastisitas model fixed effect yang dipakai pada penelitian ini tidak mengandung heteroskedastisitas. 


\section{Pemilihan Mata Uang Jangkar}

Pemilihan mata uang jangkar dilakukan sebagai kelanjutan dari adanya kemungkinan pembentukan mata uang tunggal kawasan. Sebuah negara kawasan di sarankan mematok mata uang mereka ke dalam satu mata uang yang sama, dan memiliki pengaruh (apresiasi) di wilayah tersebut. Adanya krisis di wilayah Asia dan berimbas pada hampir seluruh negara di dunia membuat kredibilitas sistem nilai tukar tetap unilateral di negara ASEAN menurun. Dengan adanya hal tersebut dapat membuka adanya peluang yang lebih besar untuk membentuk integrasi moneter atau keuangan yang bertujuan untuk meningkatkan stabilitas nilai tukar kawasan.

Kusuma et al (2013) menjelaskan bahwa mekanisme nilai tukar (ERM), telah diadopsi oleh negara Eropa Union, serta menetapkan mata uang Euro sebagai mata uang jangkar bagi negara kawasan Eropa Union. Mata uang Euro telah memberikan bukti bahwa dia mampu bertahan terhadap hantaman krisis, sejak ditetapkan nya Euro sebagai mata uang tunggal dari tahun 1999 hingga tahun 2012 pergerakan nilai tukar Euro terhadap Dollar mengalami kestabilan. Hal tersebut merupakan bukti dari kesuksesan mata uang Euro sebagai mata uang yang kuat terhadap adanya krisis serta mampu menjaga stabilitas ekonomi di kawasan Eropa Union.

Penelitian sebelumnya telah mengadopsi beberapa alternatif mata uang yang dapat digunakan oleh negara ASEAN sebagai mata uang jangkar, antara lain: USD, Jepang Yen, China Renminbi, Eropa Euro, dan adanya tambahan mata uang Singapura Dollar karena mata uang ini dianggap memiliki pengaruh yang cukup dominan di wilayah ASEAN. Pertimbangan menggunakan SGD sebagai alternatif mata uang jangkar adalah Singapura merupakan negara di wilayah ASEAN yang tergolong sebagai negara maju, selain itu perekonomian negara Singapura juga masuk dalam salah satu kategori paling terbuka di dunia atau income perkapitanya lebih tinggi jika dibanding negara anggota ASEAN lainnya.

Frankel dan Wei dalam Kawai dan Pontines (2014) memaparkan sebuah model yang dibuat dengan meregresi perubahan nilai dari mata uang kawasan terhadap Eropa Euro (Euro), China Renminbi (RMB), Jepang Yen (JPY), US Dollar (USD), dan Singapura Dollar (SGD) yang kemudian di bagi dengan New Zealand Dollar (NZD) terhadap mata uang lokal kawasan 9 negara anggota ASEAN.

Tabel 2 menunjukkan hasil regresi OLS dari penentuan pemilihan mata uang jangkar yang di usulkan sebagai mata uang alternatif kawasan ASEAN terhadap mata uang lokal kawasan ASEAN. Dari hasil tersebut dapat menunjukkan mata uang mana yang dapat memberikan adanya pengaruh (apresiasi) yang kemudian dapat di adopsi sebagai alternatif mata uang tunggal kawasan ASEAN dengan melihat adanya respon mata uang lokal terhadap mata uang alternatif kawasan.

Dapat diketahui bahwa mata uang Singapura Dollar (SGD) hampir di seluruh negara anggota ASEAN menunjukkan adanya pengaruh yang signifikan dengan melihat dari hasil prob. yang menunjukkan angka di bawah tingkat kesalahan (0.05). Selain mata uang SGD, terdapat dua mata uang jangkar lain yang juga memiliki pengaruh yang signifikan di beberapa negara anggota ASEAN, namun hasil yang menunjukkan signifikan masih tidak sebanyak mata uang jangkar SGD. Oleh karena itu, dapat diambil kesimpulan dari hasil uji untuk pemilihan mata uang jangkar, negara ASEAN di sarankan untuk mematok mata uang mereka ke dalam Singapura Dollar (SGD).

\section{Simpulan}

Kesimpulan yang diperoleh dari adanya penelitian ini diantaranya, melalui persamaan indeks OCA negara ASEAN belum siap membentuk mata uang tunggal kawasan karena belum terdapat kedekatan nilai tukar bilateral (belum ada pergerakan yang sama), serta belum adanya siklus bisnis yang sinkron. Melalui pemilihan dari beberapa mata uang jangkar yang dapat digunakan sebagai alternatif mata uang tunggal di wilayah ASEAN, menunjukkan hasil bahwa mata uang Singapura Dollar (SGD) memberikan dampak yang cukup signifikan hampir di seluruh mata uang anggota ASEAN, jika dibandingkan dengan mata uang alternatif lainnya. Hal ini mengindikasikan bahwa apabila kawasan ASEAN mematok mata uang mereka ke dalam SGD akan memberikan dampak apresiasi dan stabilitas pada mata uang kawasan.

\section{Saran}

Adapun keterbatasan dari penelitian ini diantaranya data yang digunakan pada beberapa negara masih belum lengkap, metode yang digunakan masih menggunakan model panel statis, dalam studi mendatang dapat dikembangkan dengan menggunakan model panel dinamis.

\section{Referensi}

Achsani, N. A., \& Partisiwi, T. (2010). Testing the feasibility of ASEAN+3 single currency comparing optimum currency area and clustering approach. International Research Journal of Finance and Economics, 37, 79-84.

Ahn, C., Kim, H. B., \& Chang, D. (2006). Is East Asia fit for an optimum currency area? An assessment of the economic feasibility of a higher degree of monetary cooperation in East Asia. The Developing Economies, 44(3), 288-305. https://doi.org/10.1111/j.17461049.2006.00018.x

Alvarado, S. (2014). Analysis of the optimum currency area for ASEAN and ASEAN+3. Journal of US-China Public Administration, 11(12), 9951004. https://doi.org/10.17265/1548-6591/2014.12.005

Bayoumi, T., \& Eichengreen, B. (1997). Ever closer to heaven? An optimum-currency-area index for European countries. European Economic Review, 41, 761-770. https://doi.org/10.1016/S00142921(97)00035-4

Crowley, P. M. (2015). A single currency for Nafta? North American Economic and Financial Integration, 10, 153-173. https://doi.org/10.1016/S1064-4857(04)10009-0

Frankel, J. A., \& Rose, A. K. (1996). The endogeneity of the optimum currency area criteria in East Asia. In NBER Working Paper 5700. https://doi.org/10.1016/j.econmod.2009.08.004

Friskandini, N. A. (2016). Pembentukan optimum currency area bagi ASEAN5+3 (Indonesia, Singapura, Malaysia, Thailand, Filiphina, Jepang, China, dan Korea Selatan). Airlangga.

Greene, W. H. (2008). Econometric analysis (fifth). Pearson Education, Inc., Upper Saddle River, New Jersey, 07458.

Gujarati, D. N. (2003). Basic econometrics (Fourth). Mc Graw Hill.

Henning, C. R. (2012). Choice and coercion in East Asian exchange rate regimes.

https://doi.org/10.4324/9780203797495

Kawai, M., \& Pontines, V. (2014). The Renminbi and exchange rate regimes in East Asia. In ADBI Working Paper Series (Issue 484). https://doi.org/10.1007/9780815726128

Kundera, J. (2012). The theory of an 'optimum currency area.' Wroclaw Review of Law, Administration \& Economics, 2, 1-28. https://doi.org/10.2478/wrlae-2013-0007

Lestari, E. P. (2011). Intensitas perdagangan dan keselarasan siklus bisnis di 
ASEAN-4 dan Uni Eropa. Ekonomi Pembangunan, 12(2), 163-186.

McKinnon, R. I. (1963). Optimum currency areas. The American Economic Review, 53(4), 717-725. https://doi.org/10.4135/9781412952613.n368

Mohseni, R. M., \& Azali, M. (2014). Monetary integration and optimum currency area in ASEAN+3: What we need for a new framework? International Journal of Economics and Financial Issues, 4(2), 277 285.

Mongelli, F. P. (2002). "New" views on the optimum currency area theory: What is EMU telling us? In European Central Bank Working Paper Series.
Mundell, R. A. (1961). A theory of optimum currency areas. The American Economic Review, 51(4), 657-665.

Prasanti, T. A., Wuryandari, T., \& Rusgiyono, A. (2015). Aplikasi regresi data panel untuk pemodelan tingkat pengangguran terbuka kabupaten/kota di Provinsi Jawa Tengah. Gaussian, 4(3), 687-696.

Wiranata Kusuma, D. B., Abud Ashif, S. M., Harahap, A. M., \& Omarsyah, M. A. (2013). The role of Asean Exchange Rate Unit (AERU) for Asean-5 monetary integration: an optimum currency area criteria. Buletin Ekonomi Moneter Dan Perbankan, 1-30. https://doi.org/10.21098/bemp.v15i3.68. 